\title{
UAS TEORI KOMUNIKASI
}

UAS Individu Membuat Review Dari Jurnal Penelitian Dalam Bentuk Makalah ( Paper )

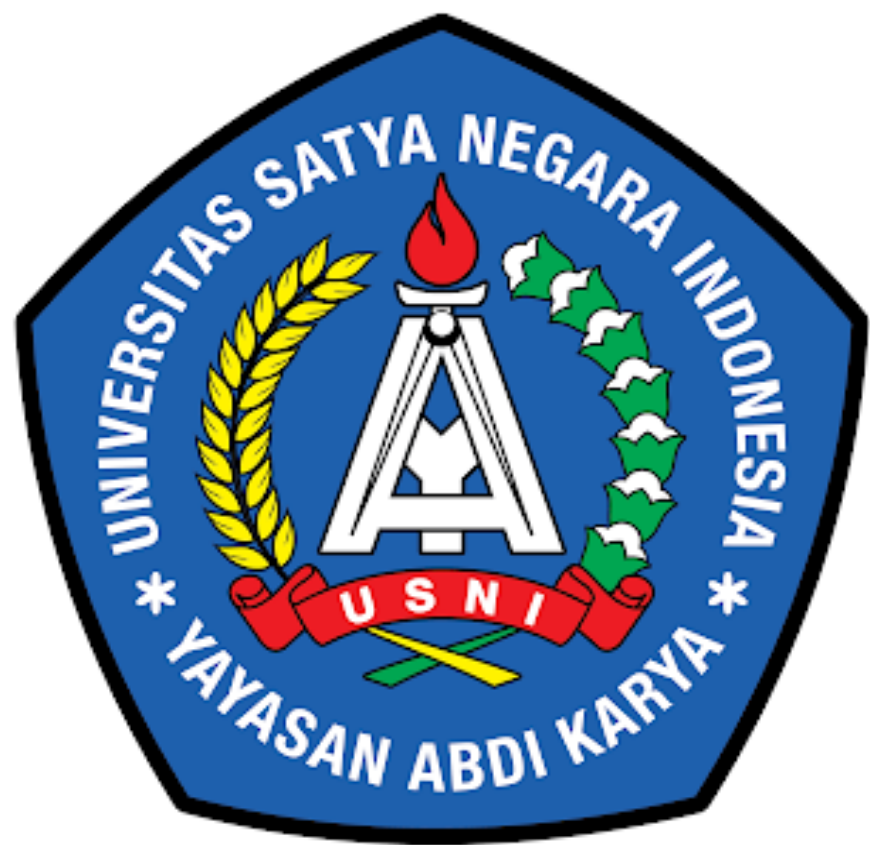

Di susun oleh : Adam Rihbi Elanda ( 180900025 )

Mata kuliah : Teori Komunikasi

Nama dosen : Radita Gora Tayibnapis, S.Sos, M.M.

\author{
FAKULTAS FISIP \\ JURUSAN ILMU KOMUNIKASI \\ UNIVERSITAS SATYA NEGARA INDONESIA
}




\section{DAFTAR ISI}

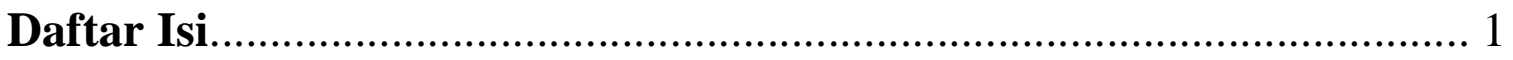

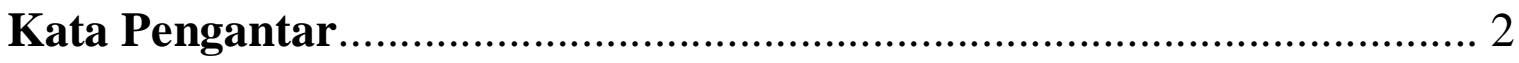

\section{BAB I PENDAHULUAN}

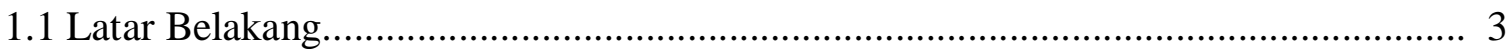

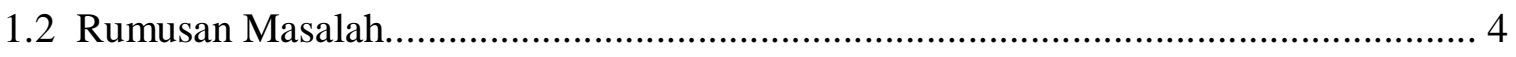

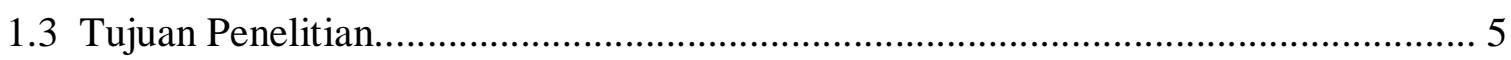

\section{BAB II PEMBAHASAN}

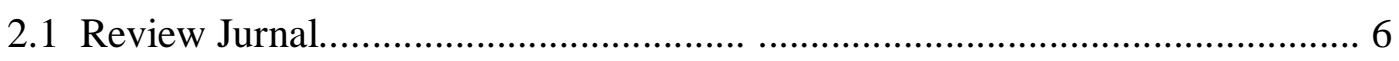

2.2 Metode Penelitian......................................................................................... 7

\section{BAB III PENUTUP}

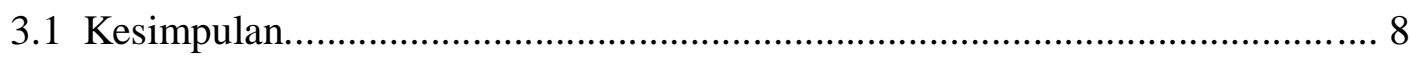

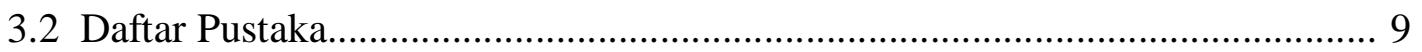




\section{KATA PENGANTAR}

Segala puji dan syukur kami panjatkan kehadirat Allah SWT yang telah melimpahkan rahmat dan hidayah-Nya kepada kita semua. Shalawat serta salam semoga tercurah kepada Rasulullah SAW beserta keluarganya.

Penulisan review jurnal yang berjudul "Social Capital Of Entrusted Service Agents For Imported Fashion And Cosmetics Products ( Modal Sosial Para Agen Jasa Titipan Untuk Produk Fashion Dan Kosmetik Impor ).” Penulisan review jurnal ini bertujuan untuk menyelesaikan tugas Teori Komunikasi dari pak Radita Gora Tayibnapis, S.Sos, M.M. Dalam penulisan review ini, kami menyadari sepenuhnya bahwa penulisan ini masih jauh dari kesempurnaan karena pengalaman dan pengetahuan penulis yang terbatas. Oleh karena itu, kritik dan saran dari semua pihak sangat kami harapkan demi terciptanya proposal yang lebih baik lagi untuk masa mendatang.

Jakarta, Januari 2021

Adam Rihbi Elanda 


\section{BAB I \\ PENDAHULUAN}

\subsection{Latar Belakang}

Kehadiran agen jasa yang dipercaya di Indonesia bisa dikatakan sebagai aktivitas baru yang dimilikinya berkembang menjadi profesi di sektor informal. Saat ini profesi semacam ini semakin marak populer dan disukai oleh anak muda dan dewasa sebagai pekerjaan sampingan yang tidak mengganggu orang lain kegiatan. Peran agen layanan yang dipercaya dapat dilakukan secara individu atau kelompok. Ini menunjukkan itu ada ekspansi baru di sektor bisnis sehingga bisa membangun berbagai sumber daya manusia baru itu memiliki potensi untuk meningkatkan perputaran finansial di antara para pebisnis amatir. Bagi pekerja di industri dan pelajar, pekerjaan sebagai agen layanan yang dipercaya sudah tidak ada lagi dianggap sebagai pekerjaan sampingan. Sebab, jumlah agen layanan yang dipercaya saat ini semakin meningkat. Banyak orang mencoba mendapatkan keuntungan dari bisnis ini dengan menjadi bagian dari agen penjualan. Melalui akses ke penyediaan barang yang dimiliki, para agen jasa yang dipercaya juga dapat menjalankan usahanya tanpa harus memiliki izin usaha tetap untuk usaha tertentu.

Agen jasa yang dipercaya bisa dikatakan cukup berani mensuplai produk dari luar negeri bukan hanya dari kawasan Asia, tetapi juga dari Australia dan Eropa. Ini adalah upaya yang dilakukan oleh yang dipercayakan agen layanan untuk bisa mendapatkan penghasilan tambahan. Jumlah agen jasa yang dipercaya terus meningkat karena orang beranggapan bahwa pekerjaan ini tidak mengkonsumsi banyak energi, tidak membutuhkan keahlian khusus, dan tidak mengganggu orang lain kegiatan. Bahkan ada yang menganggap menjadi bagian dari agen jasa yang dipercaya juga bisa menjadi sarana untuk berwisata di luar negeri untuk mensuplai barang, terutama saat menjadi agen jasa yang dipercaya untuk produk impor.

Jadi, dalam hal ini pemerintah mengenakan pajak atas barang yang dibawa dari luar negeri, bahkan sekecil apapun. Ini adalah dasar untuk pengawasan bisnis jasa yang dipercayakan. Diakui oleh banyak pihak termasuk Direktur Eksekutif Pusat Perpajakan Indonesia Analisis (CITA), Yustinus Prastowo, bahwa saat ini belum ada aturan tegas yang mengatur perincian bisnis jasa yang dipercayakan. Jadi, ada celah bagi para pebisnis ini untuk memanfaatkannya. Salah satunya adalah dengan membelah atau membagi barang belanjaan menjadi beberapa orang. Di satu sisi, pemerintah sedang agresif untuk mengontrol agen 
layanan yang dipercayakan. Namun di sisi lain, pemerintah perlu berhati-hati dalam masuk mendisiplinkan usaha jasa yang dipercayakan, karena dikhawatirkan upaya pemerintah justru akan membuahkan hasil menjadi kontra-produktif.

Selain itu, agen jasa yang dititipkan juga diminta untuk melakukan aktivitas jual beli melalui platform resmi seperti di e-commerce, bukan melalui media sosial. Aturan untuk dipercayakan agen layanan harus jelas karena ini adalah fenomena baru yang memanfaatkan teknologi. Walaupun Banding telah dikeluarkan oleh Pemerintah, tetapi agen layanan yang dipercaya masih melanggar peraturan di menjual produk melalui media sosial dan hubungan lain yang terhubung melalui media sosial mereka akun. Soal larangan pemerintah mempercayakan agen layanan berjualan di media sosial, banyak Pihak mengungkapkan bahwa pemerintah tidak berhak melarang bisnis ini karena jenis ini bisnis belum ada atau belum diatur dalam regulasi.

Diantara yang cukup meresahkan adalah produk fashion, aksesoris, dan kosmetik itu dibeli langsung dari luar negeri atau produk impor yang tidak dilegalisir di dalam negeri jadi ini cukup meresahkan bagi pasar retail, termasuk adanya barang yang keluar masuk melalui imigrasi itu tidak teridentifikasi. Selain itu, agen layanan yang dipercaya mampu membangun hubungan sosial yang lebih luas, sehingga konsumsi barang berlangsung terus menerus. Ini adalah kesempatan bagi agen layanan yang dipercaya untuk memasok secara masif karena semakin banyaknya tuntutan dari relasi mereka yang dibangun di media sosial.

\subsection{Rumusan Masalah}

1. Bagaimana para agen jasa dalam melakukan titipan untuk produk Fashion dan kosmetik?

2. Metode penelitian apakah yang di gunakan dalam mereview jurnal ini ?

\subsection{Tujuan Penelitian}

1. Mengetahui cara melakukan bisnis menjadi agen jasa titipan untuk produk fashion dan kosmetik.

2. Mengetahui metode penelitian yang di gunakan dalam mereview ini secara mendalam. 


\section{BAB II \\ PEMBAHASAN}

\subsection{Review Jurnal}

Agen layanan yang dipercaya sering disebut sebagai perampas pasar konsumen. Mereka menggesernya ke sistem perdagangan yang muncul dari mulut ke mulut atau dari penjualan barang melalui konten yang diposting melalui sosial media. Hal inilah yang menarik untuk dikaji, tentang bagaimana agen layanan yang dipercaya untuk membangun relasi sosial dapat menarik konsumen dari pasar ritel resmi. Relasi sosial menjadi sarana utama para agen jasa yang dipercaya untuk bisa terus eksis, berjualan produk mereka, dan memiliki konsumen sendiri. Sehingga penting bagi service agent yang dipercaya untuk memiliki modal sosial sebagai strategi untuk mempertahankan posisinya dalam struktur penjualan produk impor itu dilakukan secara informal. Selain itu, agen layanan yang dipercayakan menjadi agen utama dalam mendominasi pelanggan dan akses para pedagang.

Para pelaku jasa yang dipercaya, melalui modal sosialnya, selalu berusaha untuk terus berproses produksi barang berjalan dan terus memasok. Saat produk industri budaya mengalami proses komodifikasi dan produksi massal untuk menyasar pasar seluas-luasnya, salah satu konsekuensi tak terhindarkan adalah munculnya perilaku konsumsi yang sinergis (Suyanto, 2017). Untuk kekuatan kapitalisme yang menghasilkan budaya dalam skala massa, konsumsi yang sinergis perilaku biasanya dengan sengaja didorong untuk berkembang.

Lebih lanjut, Nan Ling menjelaskan bahwa modal sosial melihat bagaimana kelompok berkembang dan mempertahankannya modal sosial sebagai aset kelompok, maka aset kelompok memudahkan anggotanya untuk mencapai keuntungan ekonomi atau manfaat sosial. Dalam modal sosial dari agen jasa yang dipercayakan, dapat dilihat bahwa individu aktor memanfaatkan sumber daya yang melekat dalam hubungan sosial tersebut untuk memperoleh manfaat ekonomi dari manfaat sosial.

Keberadaan agen jasa yang dipercaya menjadi perbincangan yang populer di tengah masyarakat masyarakat semakin konsumtif dan modern yang berusaha mencari kesenangan melalui atribut barang digunakan untuk mencapai nilai prestise yang tinggi di kalangan masyarakat modern. Kondisi ini dimanfaatkan oleh yang dipercayakan agen jasa agar mampu membidik pasar konsumen konsumtif guna memperoleh keuntungan lebih dan target pasar yang pasti. Dan inilah yang digunakan oleh agen layanan yang dipercayakan untuk dapat 
membidik pasar konsumtif konsumen untuk memperoleh manfaat lebih dan pasar sasaran yang pasti.

Adanya agen jasa yang dipercaya terkadang juga menarik perhatian bea cukai dan petugas cukai di bandara. Misalnya, ada sejumlah agen jasa titipan yang tertangkap di Bandara Internasional Jakarta untuk membawa barang-barang produk luar negeri dengan label merk tertentu itu tidak termasuk dalam catatan jenis barang legal yang diperdagangkan di negara tersebut. Inilah yang membuat file agen layanan yang dipercayakan harus menebus barang mereka dengan sejumlah uang.

Pengetahuan dalam modal sosial merupakan komoditas yang rentan karena penjual tidak dilindungi perilaku pembeli yang tidak terkendali. Selain karena mahalnya harga pilihan tindakan hukum, pengetahuannya cenderung begitu dipertukarkan dengan cara yang jauh dari gratis daripada harga yang optimal untuk kinerja bisnis. Pertukaran inovasi dan aktivitas yang mapan antar perusahaan, seperti perdagangan barang dan layanan, tampaknya didorong oleh keberadaan jaringan stabil dari orang-orang yang saling percaya.

Kerja sama, terutama antar kompetitor agen jasa titipan, ternyata menyediakan bisnis yang saling menguntungkan jaringan dan jaringan pelanggan dan difasilitasi oleh normanorma kepercayaan yang melekat dalam antar-perusahaan dan jaringan intra-perusahaan, termasuk jaringan yang dibangun oleh agen layanan yang dipercayakan dengan perusahaan seperti itu pemenuhan penawaran dan permintaan serta kebutuhan individu.

Peran modal sosial dalam mengurangi biaya transaksi sangat luas diakui dalam literatur modal sosial untuk memfasilitasi sistem pembelian dan penjualan informal, tetapi juga menghasilkan lebih banyak keuntungan tergantung pada kelas agen layanan yang dipercaya.

\subsection{Metode Penelitian}

\section{* Pendekatan Penelitian}

Penelitian ini menggunakan pendekatan kualitatif dengan studi kasus. Pendekatan kualitatif memusatkan perhatian pada prinsip-prinsip umum yang mendasari perwujudan sebuah makna dari gejala-gejala sosial di dalam masyarakat. Objek analisis dalam pendekatan kualitatif adalah makna dari gejala-gejala sosial dan budaya dengan menggunakan kebudayaan dari masyarakat bersangkutan untuk memperoleh gambaran mengenai kategorisasi tertentu.

Sasaran kajian dari pendekatan kualitatif adalah adalah pola-pola yang berlaku sebagai prinsip-prinsip umum yang hidup dalam masyarakat. Gejala-gejala tersebut di lihat dari 
satuan yang berdiri sendiri dalam kesatuan yang bulat dan menyeluruh. Sehingga pendekatan kualitatif sering disebut sebagai pendekatan holistik terhadap suatu gejala sosial.

Penelitian kualitatif dengan studi kasus merupakan suatu riset sosial untuk menyelidiki, memahami, dan meneliti suatu masalah yang telah terjadi. Penelitian tersebut di lakukan dengan cara mengumpulkan berbagai informasi yang akan di olah dan menghasilkan suatu solusi, sehingga masalah tersebut akan dapat terselesaikan.

Penelitian kualitatif pendekatan studi kasus memiliki tujuan untuk memberikan gambaran mendalam tentang permasalahan pada suatu objek penelitian. Kasus yang di teliti cenderung khusus dan pada memerlukan waktu cukup lama. Penelitian studi kasus di laksanakan terhadap suatu kesatuan yang berupa kegiatan, peristiwa, program, atau kelompok pada kondisi tertentu.

\section{( Berasal Dari buku Sosiologi Komunikasi Halaman 306 -307 ).}

\section{* Paradigma Penelitian}

Paradigma konstruktivisme ialah paradigma dimana kebenaran suatu realitas sosial dilihat sebagai hasil konstruksi sosial, dan kebenaran suatu realitas sosial bersifat relatif. Paradigma konstruktivisme ini berada dalam perspektif interpretivisme (penafsiran) yang terbagi dalam tiga jenis, yaitu interaksi simbolik, fenomenologis dan hermeneutik. Paradigma konstruktivisme dalam ilmu sosial merupakan kritik terhadap paradigma positivis.

Paradigma konstruktivis bersifat reflektif dan dialektikal. Antara peneliti dan subjek yang di teliti, perlu, tercipta empati dan dan interaksi dialektis agar mampu merekonstruksi realitas yang di teliti melalui metode kualitatif.

Paradigma konstruktivisme digunakan untuk melihat realita proses pembangunan agen jasa yang dipercaya dalam menjalankan kehidupannya di dunia sosial dan untuk memahami bagaimana hubungan sosial terjalin yang dibangun oleh agen layanan swasta, termasuk prinsip, aturan dan norma, dan nilai-nilai yang dibentuk oleh agen layanan yang dipercaya dengan kelompok yang berada di bawah naungan struktur mereka.

Menurut Max Weber, dalam paradigma konstruktivisme yang digunakan dalam paradigma aksi sosial, ada lima ciri utama yang menjadi sasaran penelitian (Ritzer, 2013):

1. tindakan manusia, yaitu menurut para pelaku, mengandung makna subjektif;

2. tindakan konkret atau tindakan yang sepenuhnya bijaksana yang bersifat subjektif; 
3. tindakan yang mencakup pengaruh positif dari suatu situasi dan tindakan yang sengaja diulang dalam bentuk kesepakatan diam-diam;

4. tindakan yang ditujukan pada seseorang atau beberapa individu;

5. tindakan memperhatikan tindakan orang lain dan ditujukan kepada orang lain.

Penelitian ini juga mencoba mencari modal lain yang mendukung kinerja dan operasional perusahaan agen layanan yang dipercayakan. Untuk mengetahui modal apa saja yang dibutuhkan oleh agen jasa yang dipercayakan dalam menjalankannya. Dalam operasinya dalam perdagangan informal, teknik analisis data yang digunakan dalam penelitian ini adalah analisis modal sosial melalui interpretasi timbal balik.

\section{( Berasal dari buku Sosiologi Komunikasi Halaman 242 ).}

\section{BAB III \\ PENUTUP}

\subsection{Kesimpulan}

Berdasarkan hasil penelitian yang dilakukan maka dapat disimpulkan sebagai agen jasa titipan jadikan modal sosial sebagai prioritas utama untuk kekuatan modal yang dimiliki oleh setiap pelaku untuk dapat membangun jaringan bisnis dengan pemasok kosmetik dan produk fashion dan untuk membangun hubungan dengan pelanggan di luar lingkaran agen atau reseller layanan yang dipercaya. Selain membangun hubungan dengan pelanggan dan pemasok produk, layanan dipercayakan agen juga memperkuat hubungan jaringan mereka dengan sesama agen layanan yang dipercaya dan dengan penjual ulang. Hal tersebut dikatakan oleh informan bahwa membangun hubungan sosial dengan re-seller dan sesama titipan service agen bertujuan untuk memperkuat jaringan dengan pihak eksternal. Agen layanan yang dipercayakan Anggota suatu kelompok pada dasarnya memiliki hubungan sosial masing-masing.

Agen jasa yang dipercayakan secara keseluruhan menjual produk impor atau produk luar negeri mulai dari produk dari Asia hingga produk dari Australia dan Eropa. Mereka menjual produk luar negeri dengan harga terjangkau dengan harga yang lebih murah dari 
pada harga produk import yang dijual di showroom di mall atau vendor di Pusat perbelanjaan. Pada aspek struktur makro, upaya membangun relasi sosial tidak hanya dilakukan di lingkungan kelompok internal saja, tetapi juga di luar lingkungan sosial, seperti menargetkan individu aktor di luar kelompok dan membangun hubungan dengan eksekutif muda.

Selain itu, agen jasa yang dititipkan juga berupaya menyelundupkan barang untuk diperdagangkan dan membayar suap ke bea cukai petugas di bandara agar tidak terkena pelanggaran pajak bea cukai atau penyalahgunaan pembelian barang untuk dijual kembali. Agar tidak terpantau, agen layanan yang dipercaya harus membangun jaringan yang kuat modal sosial melalui kenalan dekat dengan petugas bea cukai.

\subsection{Daftar Pustaka}

Eriyanto. Analisis Isi. 1st ed., 2011.

M.M Siregar, Syofian. Metode Penelitian Kuantitatif. 4th ed., 2017.

M.Si, S.Sos, Bungin Burhan H. M. Dr. Pro. Sosiologi Komunikasi. 9th ed., 2017.

Radita, Gora. "Social Capital of Entrusted Service Agents for Imported Fashion and Cosmetics Products." 6, vol. 7, 2020, doi:http://dx.doi.org/10.18415/ijmmu.v7i6.1684.

(M.M Siregar) 